DOI: https://doi.org/10.36910/6775-2524-0560-2020-41-01

УДК 004.5

Булатецька Леся Віталіївна, канд. фіз.-мат. наук, доцент

https://orcid.org/0000-0002-7202-826X

Булатецький Віталій Вікторович, канд. фіз.-мат. наук, доцент

https://orcid.org/0000-0002-9883-4550

Павленко Юлія Степанівна, старший викладач

https://orcid.org/0000-0002-4065-045X

Собчук Оксана Миколаївна, канд. пед. наук, доцент

https://orcid.org/0000-0003-2185-9896

Гайдай Сергій Іванович, канд. фіз.-мат. наук

https://orcid.org/0000-0001-7803-5498

Волинський національний університет імені Лесі Українки, м. Луцьк, Україна

\title{
МЕТОДИЧНІ ОСОБЛИВОСТІ ВИВЧЕННЯ КОНЦЕПТУАЛЬНОГО ПРОЕКТУВАННЯ БАЗ ДАНИХ ПРИ ПІДГОТОВЦІ МАЙБУТНІХ ФАХІВЦІВ
}

Л. В. Булатецька, В. В. Булатецький, Ю. С. Павленко, О. М. Собчук, С. І. Гайдай. Методичні особливості вивчення концептуального проектування баз даних при підготовці майбутніх фахівців. Матеріал статті містить роз'яснення і методичні рекомендації для вивчення теми концептуального проектування баз даних в межах викладання курсів пов'язаних з дослідженням та вивченням структурованих даних в закладах вищої освіти при підготовці майбутніх фахівців. У роботі розглядається модель «сутність-зв'язок», що $\epsilon$ неформальною моделлю предметної області, та запропоновано методичні прийоми навчання моделюванню предметних областей, розглянуто впровадження компетентнісних завдань, а також типові проблеми, які виникають при викладанні цієї теми.

Ключові слова: база даних, реляційна база даних, концептуальна модель даних, ER-діаграма, предметна область, компетентнісно-орієнтовані завдання.

Л. В. Булатецкая, В. В. Булатецкий, Ю. С. Павленко, О. М. Собчук, С. И. Гайдай. Методические особенности изучения конщептуального проектирования баз данных при подготовке будущих специалистов. Материал статьи содержит разъяснения и методические рекомендации к изучению темы концептуального проектирования баз данных, в пределах преподавания курсов, связанных с исследованием и изучением структурированных данных в учреждениях высшего образования при подготовке будущих специалистов. В работе рассматривается модель «сущность-связь», что является неформальной моделью предметной области. В статье предложены методические приемы обучения моделированию предметных областей, рассмотрены внедрения компетентностных заданий, а также типичные проблемы, возникающие при преподавании этой темы.

Ключевые слова: база данных, реляционная база данных, концептуальная модель данных, ER-диаграмма, предметная область, компетентно-ориентированные задачи.

L. V. Bulatetskaya, V. V. Bulatetsky, Yu. S. Pavlenko, O. M. Sobchuk, S. I. Hayday. Methodological features of studying the conceptual design of databases in the training of future professionals. The material of the article contains explanations and methodological recommendations for studying the chapter of conceptual design of databases within the teaching of courses related to investigation and development of structured data in higher education institutions during the training of future professionals. The paper considers the entity-relationship model, which is non formal model of the subject area, and offers methods of teaching modeling of subject areas, considers the implementation of competency tasks, as well as typical problems that arise when teaching this chapter.

Keywords: database, relational database, conceptual data model, ER-diagram, subject area, competence-oriented tasks.

Постановка проблеми та аналіз досліджень. Підготовка сучасних учителів інформатики та фахівців в галузі інформаційних технологій обов'язково повинна включати предмети, пов'язані із удосконаленням базових знань, вмінь та навичок з проектування та розробки баз даних (БД), а також підвищення рівня теоретичних знань про основи БД. Перше знайомство з основами проектування та розробкою БД відбувається у закладах загальної середньої освіти. Навчальна програма профільного рівня та рівня стандарту вивчення інформатики для 10-11 класів містить розділ «Бази даних». Доцільність включення предметної змістової лінії «Системи керування базами даних» випливає із загальної мети вивчення курсу - формування в учнів інформаційної культури та інформатичної компетентності для реалізації їх творчого потенціалу та соціалізації у суспільстві завдяки здатності до ефективного використання засобів сучасних інформаційно-комунікаційних технологій [1-5]. У шкільному посібнику Завадського I. [6] значна увага приділяється концептуальному проектуванню БД та побудові ER-діаграми. При цьому тема «Проектування моделі бази даних» логічно передує темі «Створення реляційної бази даних» та знайомству з системами керування базами даних (СКБД).

У закладах вищої освіти бази даних вивчаються студентами комп’ютерних спеціальностей як самостійна дисципліна або як розділ спорідненої дисципліни. Зокрема, у Волинському національному університеті імені Лесі Українки навчальними планами спеціальностей 122 Комп'ютерні науки та інформаційні технології, 014 Середня освіта (Інформатика) та 125 Кібербезпека передбачені 
дисципліни: «Бази даних та розподілені інформаційно-аналітичні системи», «Організація баз даних та знань», «Організація та обробка електронної інформації», «Проектування програмних систем», «Моделювання та аналіз систем різної природи», «Проектування інформаційних систем та системи програмування», «Проектування i розробка веб-ресурсів та забезпечення їх захисту», «Програмування та підтримка Веб-застосувань», «Платформи корпоративних інформаційних систем», у змісті яких послідовно розкриваються питання теорії баз даних, різні аспекти технологій ïx проектування, створення та використання. Також вивчення баз даних тісно пов'язане міжпредметними зв'язками 3 іншими предметами, які мають справу з структурованими даними, наприклад, «Вибрані питання теоретичної інформатики та інформаційних технологій», «Програмування скриптовими мовами» та ін. Тому природно, що процесу проектування БД при підготовці майбутніх вчителів інформатики та фахівців в галузі інформаційних технологій приділяється значна увага [7-10]. Підготовка кваліфікованих фахівців передбачає формування у них вміння проектувати концептуальну модель БД відповідної предметної області. Для цього необхідні не лише глибокі знання теоретичних основ побудови та опрацювання БД, а також уміння аналізувати предметну область, на основі аналізу та опитування фахівців визначати іï сутності, атрибути та зв'язки. Серед компетентностей, яких мають набути здобувачі вищої освіти під час вивчення теорії побудови БД, можна виокремити такі загальні та фахові компетентності, як [11]:

- здатність до абстрактного мислення, аналізу та синтезу;

- здатність застосовувати знання у практичних ситуаціях;

- здатність до пошуку, оброблення та аналізу інформації з різних джерел;

- здатність генерувати нові ідеї (креативність);

- здатність працювати в команді;

- здатність розробляти та управляти проектами;

- здатність приймати обгрунтовані рішення;

- здатність оцінювати та забезпечувати якість виконуваних робіт;

- здатність до логічного мислення, побудови логічних висновків, використання формальних мов і моделей алгоритмічних обчислень, проектування, розроблення й аналізу алгоритмів, оцінювання їх ефективності та складності, розв'язності та нерозв'язності алгоритмічних проблем для адекватного моделювання предметних областей і створення програмних та інформаційних систем;

- здатність застосовувати методології, технології та інструментальні засоби для управління процесами життєвого циклу інформаційних і програмних систем, продуктів і сервісів інформаційних технологій відповідно до вимог замовника;

- здатність до аналізу та функціонального моделювання бізнес-процесів, побудови та практичного застосування функціональних моделей організаційно-економічних і виробничотехнічних систем, методів оцінювання ризиків їх проектування.

Метою статті є розкрити особливості вивчення проектування БД при підготовці фахівців у галузі інформаційних технологій в закладах вищої освіти.

\section{Виклад основного матеріалу й обгрунтування отриманих результатів дослідження.}

Концептуальне проектування - побудова семантичної моделі предметної області. Така модель створюється без орієнтації на деяку конкретну СКБД і модель даних. Семантичні моделі головну увагу приділяють структурі даних. Найбільш поширеною семантичною моделлю є модель «сутністьзв'язок» (Entity Relationship model, ER-модель) [12]. ER-моделювання відображає логічну структуру даних так само, як блок-схеми алгоритмів відображають логічну структуру програми. Перевагою даного підходу є можливість відобразити наочно та зрозуміло для розробника загальну структуру БД. Також до переваг побудови ER-діаграм слід віднести те, що вони добре інтегруються з реляційною моделлю, яка є найбільш популярною на сьогоднішній день. Проектована БД повинна не лише забезпечити можливість зберігання даних, але й мати таку структуру, яка б дозволила формувати різноманітні запити, звіти та всю документацію, необхідну для користувачів. Розробка невеликих БД може здійснюватися і без проектування ER-моделі, так як $\epsilon$ можливість відразу розробити логічну модель даних, оскільки там чітко прослідковується структура БД. Але, якщо йдеться про великі БД, із значною кількістю об’єктів, то побудова концептуальної схеми БД допоможе уникнути помилок проектування, які легко усунути на етапі ER-моделювання, але складно виправляти, коли БД вже розроблена і знаходиться на стадії тестування або експлуатації. Крім того, якщо предметну область можна розділити на декілька тем, то ER-модель розробляють окремо для кожної теми, а потім інтегрують в загальну концептуальну модель предметної області. Розробка концептуальної моделі $\epsilon$ дуже важливим, найбільш відповідальним і найскладнішим етапом проектування БД. 
Вивчення та дослідження предметної області є однією з основних проблем, яка виникає при проектуванні БД. Адже саме на етапі проектування, ще в ER-моделі, важливо найбільш точно відтворити всі вимоги до БД. Здобувачі вищої освіти повинні розуміти, що для того, аби правильно i оптимально спроектувати БД, необхідно фактично стати фахівцем відповідної предметної області. Потрібно багато працювати з замовником, з експертами та системними аналітиками для визначення вимог до розроблюваної БД. Власне вивчення даної теми у вищих навчальних закладах при підготовці майбутніх фахівців в галузі інформаційних технологій ставить за мету розвивати вміння аналізувати предметну область, правильно визначати сутності, атрибути та зв'язки між сутностями, а також усвідомлювати важливість комунікації з замовником.

Розгляд теми «Модель сутність зв'язок» варто розпочати 3 огляду стандартизації моделі. Вперше поняття ER-моделі запровадив П. Чен в роботі [13]. Система позначень 3 цієї роботи отримала назву нотації Чена. Надалі діаграми Чена набули розвитку у багатьох інших роботах з ERмоделювання. Різні автори почали пропонувати свої елементи моделі та свою термінологію, що призвело до наявності великої кількості різних нотацій ER-діаграм [12]. Проте існують загальні принципи побудови діаграм, що лежать в основі більшості її варіантів.

При вивченні даної теми можна вести аналогію між різними позначеннями або зупинитися на одній $з$ них. Зокрема, в шкільному посібнику Завадського I. [6] використано графічні позначення сутностей і зв'язків, запропоновані П. Ченом.

Наступним етапом повинно бути вивчення основних понять моделі «сутність-зв'язок» та їх графічного подання: поняття сутності, екземплярів сутності, зв'язків між сутностями та їх властивостей (атрибутів). Також важливими поняттями, які розглядаються в даній темі, є поняття слабкої й сильної сутності, поняття кардинальності зв'язку, поняття обов'язкових і необов'язкових зв'язків та рекурсивних зв'язків. Особливу увагу потрібно приділити розширеній моделі «сутністьзв'язок».

При вивченні основ проектування БД важливо, щоб майбутні фахівці не лише зрозуміли принципи побудови ER-моделі, а й навчилися розробляти прості проекти. Тому, з метою набуття досвіду роботи з проектування БД, зокрема, формування вмінь і навичок правильно відображати особливості предметної області у концептуальних моделях БД, здобувачам вищої освіти доцільно пропонувати індивідуальні завдання, які полягають в розробці концептуальної моделі для реальної предметної області. Для цього майбутні фахівці повинні вивчити предметну область, проаналізувати iii, визначити сутності й атрибути, сформулювати бізнес правила, на основі яких визначаються зв'язки між сутностями для проектованої області. Виконання індивідуальних завдань 3 проектування ERдіаграми є компетентнісним, оскільки вони стосуються реальних життєвих ситуацій, які потрібно вирішувати розробникам БД. Таким чином вивчення даної теми дозволить забезпечити формування у майбутніх фахівців інформаційно-аналітичної компетентності як характеристики особистості, що відображає іiі готовність і здатність ефективно здійснювати пошук, збір, аналіз, обробку інформації і продуктивно використовувати іiі в процесі розробки ER-моделі БД певної предметної області. [11].

При розробці варіантів індивідуальних завдань варто спочатку передбачити їх представлення у вигляді мінімального опису реальної предметної області. При такому формулюванні завдання, здобувачам вищої освіти, як правило, складно визначити сутності й атрибути, якщо вони мало ознайомлені 3 предметною областю, не знають принципів роботи підприємства, для якого розробляється БД. Але формулювання такого типу завдань дозволить здобувачам вищої освіти усвідомити об'єм роботи, яку повинен виконати проектант та важливість комунікації з замовником, експертами з предметної області та системними аналітиками при визначенні вимог до розроблюваної БД.

Наприклад, якщо буде сформульовано завдання розробити концептуальну модель БД книжкового магазину, то, ймовірно, студент не повною мірою зможе зрозуміти, що саме від нього вимагається. Якщо далі уточнити завдання і вказати, що мета розробки полягає у забезпеченні адміністрації магазину довідковою інформацією про наявні книги, про авторів, видавців та ведення обліку надходження і продажу книг, то майбутні фахівці зможуть визначити мінімальні вимоги до розроблюваної БД. Оскільки ER-діаграма повинна відображати всі бізнес правила предметної області, які, в свою чергу, визначають сутності, атрибути, зв'язки та ін., то без детального аналізу предметної області проектант може не врахувати деякі їі важливі аспекти. Тому на це потрібно звернути особливу увагу при підготовці майбутніх спеціалістів.

При ER-моделюванні сутність має унікальне ім'я у межах системи, що описується та дозволяє моделювати клас однотипних об'єктів. Оскільки сутність відповідає деякому класу однотипних об'єктів, то передбачається, що в системі існує багато екземплярів даної сутності. Наприклад, сутність «Автор» предметної області «Книжковий магазин» має багато екземплярів, тобто список 
авторів. Об'єкт, якому відповідає сутність, має набір атрибутів, які характеризують його властивості. При цьому набір атрибутів повинен бути таким, щоб можна було розрізняти конкретні екземпляри сутності. Сутностям і зв'язкам відповідає певний набір атрибутів. Сутність може мати принаймні один атрибут, а зв'язок може взагалі не мати жодного атрибуту. Сутність може бути об'єктом із реальним або абстрактним існуванням. Наприклад, Сутності «Книга», «Видавець» - це типи сутностей, що відповідають об'єктам із реальним існуванням, а сутність «Продажі»- це тип сутності, що відповідає об'єкту із абстрактним існуванням [12]. Модель «сутність-зв'язок» не дає однозначного вирішення для визначення проектантом вимог до ії об'єктів. Наприклад, не завжди можна визначити, до якого елемента моделі можна віднести певний об'єкт (до типу сутності, зв'язку або атрибута). Наприклад, при визначенні набору сутностей предметної області «Книжковий магазин» об' єкт «Автор», можна розглядати, як окрему сутність, або як атрибут сутності «Книга», а об'єкт «Продажі» теж можна розглядати, як окрему сутність, або як об'єкт зв'язок. Аналіз предметної області та побудова іiі моделі є суб'єктивним процесом, тому учасники навчального процесу можуть створювати різні але допустимі інтерпретації одного й того самого факту. Вибір варіанту значною мірою залежить від проектанта і його бачення даної проблеми, що стимулює розвиток логічного мислення. В результаті, ER-модель книжкового магазину може мати різну інтерпретацію, де набір сутностей не обов'язково співпадатиме. Також слід зауважити, що атрибут реалізувати значно простіше, ніж сутність або зв'язок.[12]

Не менш важливим завданням є визначення зв'язків між сутностями в проектованій ERмоделі. Майбутні фахівці повинні навчитися будувати зв'язки між сутностями, які визначаються на основі бізнес правил 3 урахуванням організаційної структури й операцій, що виконуються в проектованій системі. Наприклад, для проекту «Книжковий магазин» потрібно знати чи може бути в однієї книги декілька авторів, чи тільки один. Можливо, для прикладу, в книжковому магазині $є$ в наявності тільки художня література, де один автор. Також потрібно знати, чи постачає книги в книжковий магазин посередник чи видавництво, та яка кількість постачальників. Зрозуміло, що посередник та видавництво здійснюють постачання різних книг. Також потрібно з'ясувати, як саме відбувається процес надходження книг в магазин, та як відбувається процес покупки, щоб все це відобразити в концептуальній моделі.

Висновки. Використання компетентнісних завдань в процесі підготовки майбутніх фахівців в галузі інформаційних технологій стимулює студентів до творчого пошуку вирішення життєвих проблем i досягнення професійних компетентностей. Метою компетентнісних завдань 3 проектування БД $є$ засвоєння знань та вмінь побудови ER-моделі, оцінювання іï правильності та оптимальності, виявлення та виправлення помилок. В процесі розв'язування таких завдань зростає мотивація майбутніх фахівців при розробці ER-моделі БД. Також було б доречно запровадити підготовку індивідуальних завдань 3 проектування БД для конкретних підприємств, установ чи організацій в процесі проходженні здобувачами вищої освіти виробничої практики. Наприклад, у Волинському національному університеті імені Лесі Українки згідно навчального плану підготовки бакалаврів спеціальності 122 Комп’ютерні науки та інформаційні технології передбачено в 6 семестрі проектно технологічну практику, а здобувачі вищої освіти, які навчаються за спеціальністюі 014 Середня освіта (Інформатика), мають практику «Застосування інформаційних технологій», яку проходять на підприємствах або в комерційних установах. Одним з завдань такої практики $є$ ознайомлення 3 структурою підприємства чи установи та принципами його функціонування. Доцільно було б уточнити завдання, запропонувавши студентам на основі аналізу та комунікації 3 потенційними користувачами, спроектувати концептуальну модель вибраної предметної області для розробки БД, яка могла б використовуватися на даному підприємстві. Такого виду завдання забезпечують формування у майбутніх фахівців реального практичного досвіду.

Викладені у статті методичні прийоми навчання моделювання предметних областей та використання $з$ цією метою компетентнісних завдань можуть бути використані не лише для вивчення теми концептуального проектування баз даних в межах викладання курсів пов'язаних 3 дослідженням та вивченням структурованих даних в закладах вищої освіти при підготовці майбутніх фахівців, а також і для організації навчального процесу вчителів у системі післядипломної педагогічної освіти під час підвищення кваліфікації.

Список бібліографічного опису

1. Інформатика. Навчальна програма вибірково-обов'язкового предмету для учнів 10-11 класів загальноосвітніх навчальних закладів (рівень стандарту) - Режим доступу: https://mon.gov.ua/storage/app/media/zagalna\%20serednya/programy-10-11-klas/2018-2019/informatika-standart-10-11.docx

2. Інформатика для 10-11 класів (профільне навчання) - Режим доступу: https://mon.gov.ua/storage/app/media/zagalna\%20serednya/programy-10-11-klas/2018-2019/01/10-11-profilniy-riven.docx 


\section{Луц̧ьк, 2020. Випуск № 41}

3. Шамшина Н.В. Методичні особливості вивчення зв'язків та типів об'єднання у базах даних Microsoft Access / Н. В. Шамшина // Фізико-математична освіта. - 2018. - Випуск 1(15). - С. 339-343

4. Булатецька Л.В. Особливості вивчення мови запитів SQL профільному курсі інформатики закладів загальної середньої освіти / Л. В. Булатецька, В. В. Булатецький. Комп’ютерно-інтегровані технології : освіта, наука, виробництво. - Луцьк. - 2020.- № 39. - С. 5-10.

5. Руденко В.Д. База даних - основна складова інформаційної системи / В. Д. Руденко // Комп’ютер у школі та сім'ї.2009. - №6. - С. 48-52. - Режим доступу: http://nbuv.gov.ua/UJRN/komp_2009_6_12.

6. Завадський І.О. Основи баз даних : навч. посіб. К. : Видавець І.О. Завадський, 2011. 192 с.

7. Мулеса О.Ю. Методика навчання основам теорії нормалізації реляційної моделі даних в контексті компетентнісного підходу до підготовки фахівців у системі вищої освіти / О. Ю. Мулеса, Ф. Е. Гече, Ю. Ю. Імре // Фізико-математична освіта.- 2018. - Випуск 3(17). - С. 67-72.

8. Єфименко В. В. Особливості курсу «Проектування та опрацювання баз даних» для майбутніх вчителів інформатики / В. В. Єфименко // Науковий часопис НПУ імені М. П. Драгоманова. Серія 2 : Комп'ютерно-орієнтовані системи навчання. - 2019. - № 21. - С. 70-78. - Режим доступу : http://nbuv.gov.ua/UJRN/Nchnpu_2_2019_21_14.

9. Єфименко В. В. Деякі аспекти навчання курсу «Проектування та опрацювання баз даних» студентів інформатичних спеціальностей. Науковий часопис НПУ імені М.П.Драгоманова. Серія №2. Комп’ютерно-орієнтовані системи навчання. Київ: НПУ імені М. П. Драгоманова, 2018. № 20 (27). С. 113-118.

10. Погромська Г. Викладання баз даних на комп'ютерних спеціальностях як елемент підготовки студентів-інформатиків до професійної діяльності / Г. Погромська. Збірник наукових праць Уманського державного педагогічного університету імені Павла Тичини. - 2013. - Випуск 3. - С. 215-222. - Режим доступу: http://nbuv.gov.ua/UJRN/znpudpu_2013_3_33.

11. Стандарт вищої освіти України першого (бакалаврського) рівня ступеня «бакалавр» за галуззю знань 12 «Інформаційні технології» спеціальністю 122 «Комп'ютерні науки» [Електронний ресурс] - Режим доступу : https://mon.gov.ua/storage/app/media/vishcha-osvita/zatverdzeni\%20standarty/2019/07/12/122-kompyuterni-naukibakalavr.pdf

12. Буй, Д. Б. Формалізація моделі «сутність-зв’язок» [Текст] : монографія / Д. Б. Буй, Л. М. Сільвейструк. - Київ. нац. унт ім. Тараса Шевченка. - Київ : Київський університет, 2011. - 175 с.

13. Chen, P. P. The entity-relationship model - towards a unified view of data / P. P. Chen // ACM Transactions on Database Systems. - March 1976. - Vol. 1, №. 1. - P. 9-36;

1. Informatyka. Navchalna programa vybirkovo-obov`yazkovogo predmetu dlya uchniv 10-11 klasiv zagalnoosvitnih navchal nyh $\quad$ zakladiv (riven $\quad$ standartu) - $\quad$ Rezhym https://mon.gov.ua/storage/app/media/zagalna\%20serednya/programy-10-11-klas/2018-2019/informatika-standart-10-11.docx

2. Informatyka dlya 10-11 klasiv (profil `ne navchannya) - Rezhym dostupu: https://mon.gov.ua/storage/app/media/zagalna\%20serednya/programy-10-11-klas/2018-2019/01/10-11-profilniy-riven.docx

3. Shamshina N. Methodical Features Of Studying Relationships And Types Of Joins In Databases Microsoft Access. Physical and Mathematical Education. 2018. Issue 1(15). P. 339-343. (in Ukrainian)

4. Bulatetska L.V., Bulatetsky V.V. Features of studying the language of SQL queries in the profile course of informatics of institutions of general secondary education. // Computer-integrated technologies: education, science, production. 2020.- № 39. - P. 5-10. (in Ukrainian)

5. Rudenko V. D. Baza danyh - osnovna skladova informatsiynoi systemy / V. D. Rudenko // Kompyuter v shkoli i sim'yi .2009. - № 6. - P. 48-52. Rezhym dostupu - http://nbuv.gov.ua/UJRN/ komp _2009_6_12

6. Zavadsky I.O. Fundamentals of the databases: textbook. K. : Publ. I.O. Zavadsky, 2011. 192 p. (in Ukrainian)

7. Mulesa Oksana, Geche fedir, imre yuliy. The method of teaching the basis of theory of normalization of the data relative model in the context of the competency approach to preparation of professionals in the higher education system. Physical and mathematical education. 2018. Issue 3(17). P. 67-72.

8. Yefymenko V.V. Features of the course «Design and development of databases» for future teachers of computer science. Naukovyi chasopys NPU imeni M. P. Drahomanova. Seria № 2. Kompiuterno -oriientovani systemy navchannia. Kyiv: NPU imeni M. P. Drahomanova, . - 2019. - № 21. - S. 70-78.

9. Yefymenko V.V. Deiakiaspekty navchannia kursu «Proektuvannia ta opratsiuvannia baz danykh» studentiv informatychnykh spetsialnostei. Naukovyi chasopys NPU imeni M. P. Drahomanova. Seria № 2. Kompiuterno-oriientovani systemy navchannia. Kyiv: NPU imeni M. P. Drahomanova, 2018. №. 20 (27). S. 113-118.

10. Pogromska G. Teaching databases in computer specialties as an element of preparation of computer science students for professional activity / G. Pogromska // Collection of Scientific Papers of Uman State Pedagogical University. - 2013. - Vip. 3. - P. 215-222.

11. Standart vyshchoi osvity Ukrainy pershogo (bakalavrskogo) rivnya stupenya «bakalavr» za galuzzyu znan 12 «Informatsiynr tehnologii» spetsialnistyu 122 «Kompyuterni nauky» [Elektronnyi resurs] / Rezhym dostupu https://mon.gov.ua/storage/app/media/vishcha-osvita/zatverdzeni\%20standarty/2019/07/12/122-kompyuterni-naukibakalavr.pdf

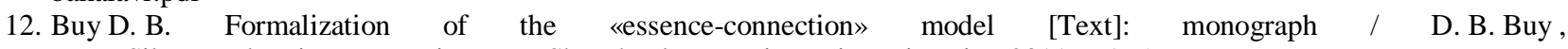
L. M. Silveystruk; Kiev. nat. Univ. Taras Shevchenko. - Kyiv: Kyiv University, 2011. - 175 p.

13. Chen, P. P. The entity-relationship model - towards a unified view of data / P. P. Chen // ACM Transactions on Database Systems. - March 1976. - Vol. 1, №. 1. - P. 9-36; 